\title{
Goal of Language Acquisition is to Develop Communications Skills
}

\author{
Patnam Sreeramulu
}

\begin{abstract}
Volumes about language teaching and language acquisition have been coming out ever since Noam Chomsky had leveled at structural linguistic theory. Books have been written about the approaches and methods of teaching a language. But the Undenying fact is that those volumes have failed to suggest an obvious impact on the listener. Though we have traditional methods such as "Audio lingual method" and "situational language teaching method", none has brought the desired result.

Keywords : About four key words or phrases in alphabetical order, separated by commas.
\end{abstract}

\section{INTRODUCTION}

Modern linguists have discarded those methods as inadequate and imprecise and are incapable of accounting for the creativity and uniqueness of individual sentences. They are prompted to focus that mere mastery over structures cannot bring communicative proficiency.

\section{A NEW CONCEPT} acts, linguists try to focus the components of meaning which is the real function of the study of a language. In order to bring forth the above said activity of the speaker-learner, they combined both grammatical and functional teaching and they called this new approach "Communicative Language Teaching" (CLT). They build their arguments on the two-fold manifestations:

$$
\begin{aligned}
& \text { a) educate English } \\
& \text { b) apply English }
\end{aligned}
$$

Earlier one force vital seekers apply English for interation reason and try to speak with language integrate communication with language teachining. The latter concept progresses language is to earn through communication and stimulates its growth.

\section{Components and objective of CLT}

- $\quad$ Language learning is learning communication.

- $\quad$ Language details are to be contextualized.

- Situation-based dialogue is the Central activity. Comprehensible pronunciation is required.

- Grammatical explanations are to be given according to their age, interest etc.,

- $\quad$ Use of native language is acceptable.

Revised Manuscript Received on January 29, 2020

* Correspondence Author

Dr. Patnam Sreeramulu*, Assistant Professor, Department of English, GITAM (Deemed to be) University, Visakhapatnam, Andhra Pradesh

(C) The Authors. Published by Blue Eyes Intelligence Engineering and Sciences Publication (BEIESP). This is an open access article under the CC BY-NC-ND license (http://creativecommons.org/licenses/by-nc-nd/4.0/)
As Linguistics is concerned with the description of speech

- Translation - method is possible.

- $\quad$ Reading and Writing are encouraged from the beginning of communication.

- $\quad$ Use linguistic system effectively.

- Teachers follow any method that should motivate them to work with the language.

- $\quad$ Language is created by the individual.

- Students are expected to interact with other students.

- Intrinsic motivation will spring from communication and not from structure by language.

\section{ACTIVITIES}

CL T has got two activities

1. Functional communicative activities.

2. Social interactive activities.

The "Functional Communicative Activities" syllabus is designed for school going students. They are provided with tasks such as comparing pictures, noting equivalence and variations, inventingabsentcolums in chart etc

"Social Interactive activities" add discussion, period, chatting and act, frolic, skits and debates. Successful interaction is a combined responsibility of both the caller and a listener.

Seeker should contribute for gains and thereby infant In an inter subordinate path. The speaker should

1. Accommodate the communicative way two participants in class room.

2. Should do as an co-ordinate participant before the end of the seeking - giving group.

3. Should give knowledge, same and followed learning grip and institutaional levels

following are the important role of the teachers.

- Presentation of mini-dialogues, reflecting functional and situational-based activities.

- $\quad$ Oral practice (class repetition, group ,individuals)

- $\quad$ Enquire andinquirdepend act (maybe direct or indirect questions)

- Study one of the basic communicative expressions by way of using one of the grammatical structures which exemplify the function $(\mathrm{V}+\mathrm{ing})$

- $\quad$ Oral interpretative activity.

- Oral production activities (free conversation)

- $\quad$ Sampling of assignments.

- $\quad$ Evaluation of learning

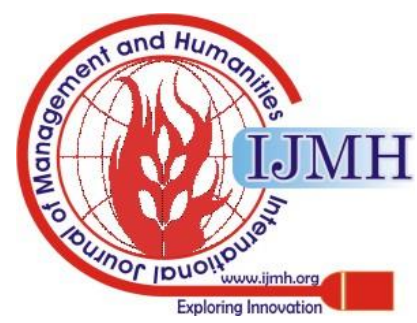




\section{The diagram shows}

"! Components of CLT

"! Grammatical Competence "! Social Interaction "! Functional Communicative activity

\section{RESULT AND DISCUSSION}

Communicative teaching describes learner's ability basic \& other skills in situation that are commonly encountered every day. The opportunity to produce comprehensive output in the meaningful interaction appears to be a crucial factor in the learner's development of language. Communicative language Teaching quickly over - - shadowed the formal situational and audio-lingual methods. This approach is acclaimed and accepted by all linguists.

Johnson identify 5main divisions specify present application of deliver technique:

a. Relatedness- speechsays the appropriateness of the situations depending on the setting.

b. focus-Seekerswants to understand message .

c. Psycholinguistic-CLT asks the learners use process cognitive \& other processing vital factors of later language teaching.

d. hard Learners seek from their mistake

e. Free practice- CLT helps learners to use variety of sub skills instead of practicing personal abilities one place.

\section{CONCLUSION}

To conclude the arguments, it is said that language belongs to the humanistic tradition. Linguists are of the view in the CL T oneargue "learners first, learning second". It gives priority to engage readers. This is an approach rather than a method is learner - centered and not speaker centered. This approach formed a substitute for various other approaches and methods. But how it works in our India context?

\section{REFERENCES}

1. Lyons John. Language and Linguistics. Cambridge University Press, 1995.

2. P.R. Mathews. Linguistics. Oxford University Press, 1981.

3. Richards C. Jack. Approaches and Methods In language Teaching Cambridge University Press, 2005.

4. Yule George. The study of Language. Cambridge University Press.

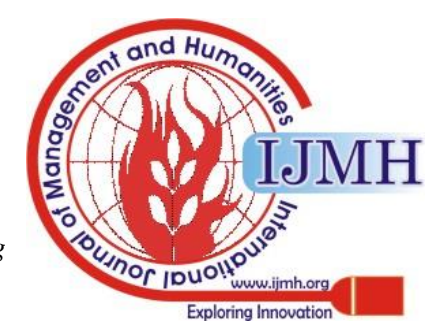

